\title{
Oidium neolycopersici: Intraspecific Variability Inferred from Amplified Fragment Length Polymorphism Analysis and Relationship with Closely Related Powdery Mildew Fungi Infecting Various Plant Species
}

\author{
T. Jankovics, Y. Bai, G. M. Kovács, M. Bardin, P. C. Nicot, H. Toyoda, Y. Matsuda, R. E. Niks, and L. Kiss
}

First, third, and ninth authors: Plant Protection Institute of the Hungarian Academy of Sciences, H-1525 Budapest, P.O. Box 102, Hungary; second and eighth authors: Laboratory of Plant Breeding, Wageningen University, P. O. Box 386, 6700 AJ Wageningen, The Netherlands; third author: Department of Plant Anatomy, Eötvös Loránd University, Pázmány Péter sétány 1/C, H-1117 Budapest, Hungary; fourth and fifth authors: INRA, Centre de Recherches d'Avignon, Unité de Pathologie Végétale, 84140 Montfavet, France; sixth and seventh authors: Laboratory of Plant Protection and Biotechnology, Department of Agricultural Science and Technology, Faculty of Agriculture, Kinki University, 3327-204 Nakamachi, Nara, 631-8505, Japan.

Accepted for publication 29 November 2007.

\begin{abstract}
Jankovics, T., Bai, Y., Kovács, G. M., Bardin, M., Nicot, P. C., Toyoda, H., Matsuda, Y., Niks, R. E., and Kiss, L. 2008. Oidium neolycopersici: Intraspecific variability inferred from amplified fragment length polymorphism analysis and relationship with closely related powdery mildew fungi infecting various plant species. Phytopathology 98:529-540.

Previous works indicated a considerable variation in the pathogenicity, virulence, and host range of Oidium neolycopersici isolates causing tomato powdery mildew epidemics in many parts of the world. In this study, rDNA internal transcribed spacer (ITS) sequences, and amplified fragment length polymorphism (AFLP) patterns were analyzed in 17 $O$. neolycopersici samples collected in Europe, North America, and Japan, including those which overcame some of the tomato major resistance genes. The ITS sequences were identical in all 10 samples tested and were also identical to ITS sequences of eight previously studied $O$. neolycopersic $i$ specimens. The AFLP analysis revealed a high genetic diversity in $O$. neolycopersici and indicated that all 17 samples represented different genotypes. This might suggest the existence of either a yet unrevealed sexual reproduction or other genetic mechanisms that maintain a high genetic variability in $O$. neolycopersici. No clear

correlation was found between the virulence and the AFLP patterns of the $O$. neolycopersici isolates studied. The relationship between $O$. neolycopersici and powdery mildew anamorphs infecting Aquilegia vulgaris, Chelidonium majus, Passiflora caerulea, and Sedum alboroseum was also investigated. These anamorphs are morphologically indistinguishable from and phylogenetically closely related to $O$. neolycopersici. The crossinoculation tests and the analyses of ITS sequences and AFLP patterns jointly indicated that the powdery mildew anamorphs collected from the above mentioned plant species all represent distinct, but closely related species according to the phylogenetic species recognition. All these species were pathogenic only to their original host plant species, except $O$. neolycopersici which infected S. alboroseum, tobacco, petunia, and Arabidopsis thaliana, in addition to tomato, in cross-inoculation tests. This is the first genome-wide study that investigates the relationships among powdery mildews that are closely related based on ITS sequences and morphology. The results indicate that morphologically indistinguishable powdery mildews that differed in only one to five single nucleotide positions in their ITS region are to be considered as different taxa with distinct host ranges.
\end{abstract}

Since the late 1980 s, powdery mildew epidemics have become a problem in tomato (Solanum lycopersicum L.) production worldwide $(28,48)$. Recent studies have shown that the causal agent of this apparently novel disease is Oidium neolycopersici L. Kiss in Europe, North America, and Japan $(34,36,43)$. In Australia, a distinct powdery mildew species, O. lycopersici Cooke \& Massee, was responsible for powdery mildew outbreaks on tomato (34). Both powdery mildew species were identified in herbarium materials deposited several decades ago which suggests that they both had infected tomato long before the recent epidemics started (34). The sexual stages of these two Oidium species have not been detected so far.

$O$. neolycopersici has become economically much more important than $O$. lycopersici. As a consequence, all the efforts to breed

Corresponding author: L. Kiss; E-mail address: lkiss@nki.hu

* The $e$-Xtra logo stands for "electronic extra" and indicates that there is a supplemental figure available online showing a part of a cross-inoculation experiment.

doi:10.1094/PHYTO-98-5-0529

(C) 2008 The American Phytopathological Society tomato cultivars resistant to powdery mildew have dealt with this powdery mildew species $(3-5,41)$ especially because almost all tomato cultivars available worldwide are susceptible to $O$. neolycopersici $(38,41,43,48)$. Wild Solanum spp. (syn. Lycopersicon spp.) were evaluated to be promising sources of resistance to $O$. neolycopersici $(41,44)$. To date, six major resistance genes, designated $O l-1$ to $O l-6(4,5)$ and three quantitative trait loci (QTLs) (3) were identified for resistance to O. neolycopersici.

Resistance breeding to $O$. neolycopersici could be complicated by a yet unexplored intra-specific variability in the populations of this pathogen. Although sexual reproduction has not been observed yet in this fungus, limited data suggested that there is considerable variation in the pathogenicity, virulence, and host range of various strains $(4,28,40)$. For example, a recent study showed that the resistance conferred by the individual $O l$ genes (Oll to Ol6) were effective to most, but not all, of the European and United States powdery mildew strains tested (4). This suggested that $O$. neolycopersici might consist of various races, distinguished based on differences in their infection patterns, and the resistance conferred by certain $\mathrm{Ol}$-genes is race-specific (4). Other studies have lead to the same conclusion. Kashimoto et al. 
(30) showed that the tomato cv. Grace bred in the Netherlands showing resistance to several European and United States strains of $O$. neolycopersici, was susceptible to a Japanese isolate, KTP01 , of the pathogen. In glasshouse trials, this cultivar also developed severe symptoms following inoculation with French isolates of $O$. neolycopersici, including the single spore isolate Et1 (63). In another study, important differences were found in the virulence spectrum of four other European $O$. neolycopersici strains, coming from the Czech Republic, Netherlands, United Kingdom, and Germany, tested on many accessions of several wild Solanum (Lycopersicon) species (40). According to Lebeda and Mieslerová (40), the four European strains included in their work represented three different races of $O$. neolycopersici. Genetic analyses would be needed in $O$. neolycopersici to explain the differences reported in the virulence of various isolates and especially in those that might represent different races as suggested by Lebeda and Mieslerová (40) and Bai et al. (4).

Another matter associated with tomato powdery mildew is the reported contradictions in the host range of $O$. neolycopersici. Some authors reported a wide host range, based on artificial inoculations, suggesting that $O$. neolycopersici is polyphagous $(39,68)$, while others found experimentally that it can infect only a few plant species other than tomato $(24,29,38)$. In fact, it was not shown by any studies that the host range of $O$. neolycopersici includes any hosts other than tomato under natural conditions. Naturally occurring $O$. neolycopersici strains have not been identified on plants other than tomato so far. However, there are a number of powdery mildews, such as E. aquilegiae, E. catalpae, E. macleayae, and an Oidium sp. infecting Chelidonium majus whose anamorphs are morphologically indistinguishable from $O$. neolycopersici and are closely related to $O$. neolycopersici based on the internal transcribed spacer (ITS) sequences of the nuclear ribosomal DNA (rDNA) $(13,26,36)$. The exact host ranges of these, and similar powdery mildews are not known. Thus, it is at present unclear whether all these pathogens represent, in fact, one single powdery mildew fungus that sometimes produces the sexual stage and exhibits a $99 \%$ similar ITS sequence in various samples, and is capable to infect a wide range of host plants, including tomato. Alternatively, the powdery mildew fungi found on different hosts (including tomato), and exhibiting a similar morphology and ITS sequence, might represent distinct taxa with restricted host ranges. If the first presumption is correct, a number of weeds, ornamentals, and other plants could serve as sources of inoculum for tomato powdery mildew infections.

The species recognition in the Erysiphales is based on the morphological characteristics of the teleomorph and anamorph stages and the host ranges of the various taxa $(8,9,14)$. All the molecular phylogenetic studies carried out so far have shown that the differences in the rDNA ITS sequences always correlated with the delimitation of different species and formae speciales of the Erysiphales because these sequences were always identical or 99\% similar within, but always differed among, all the welldefined taxa identified based on morphological and/or host range criteria $(10,13,22,23,25,33,57)$. However, the species boundaries and the level of genetic isolation in morphologically indistinguishable powdery mildews found on different hosts, and exhibiting very similar, but not identical, ITS sequences, have not been clearly determined yet. Within such groups of the Erysiphales, sometimes considered as being species complexes (31) or consisting of cryptic species (35), phylogenetic works, including multilocus analyses, have always shown that the different ITShaplotypes were associated only with the host plant species or genera on which they were found $(21,22,25,31,46)$. These results suggested that specialization to different host plant species or genera may be sufficient to cause genetic isolation $(19,25,62)$ and the use of the phylogenetic species concept $(19,61)$ might be more appropriate to handle these powdery mildew lineages, represented by distinct ITS-haplotypes, than that of the common morpho- logical species concept. However, in the case of morphologically similar powdery mildew anamorphs infecting tomato and/or other plants, and exhibiting a 99\% similar ITS sequence, detailed crossinoculation tests and further genetic analyses are needed to clarify their exact host ranges and the level of genetic isolation within this group of powdery mildews.

Genome-wide analyses have not been used to address this problem in powdery mildews, except in Blumeria graminis, where the amplified fragment length polymorphism (AFLP) fingerprinting technique was applied to compare the genetic patterns of a number of formae speciales specialized to different monocot species (69). The AFLP method has already been successfully used to assess the genetic diversity in a number of other plant pathogenic fungi, as well, including apparently asexual ones, similar to $O$. neolycopersici, which probably exhibit a high level of clonality $(7,20,56)$. To date, only a few other applications of AFLP were reported in powdery mildew research $(52,64)$ probably because it is often difficult to obtain sufficient amounts of DNA from these obligate biotrophs that can be multiplied on living host plant tissues only. This problem limited the number of powdery mildew samples used in earlier AFLP studies and has become a limiting factor in our work, as well. In spite of this difficulty, we chose the AFLP method to provide a measure of genetic diversity in $O$. neolycopersici and compare its genome-wide patterns with those of morphologically similar, and phylogenetically closely related powdery mildew anamorphs, because of its reliability and accessibility for the present work. ITS sequence analyses were also used to confirm the precise identity of the powdery mildew anamorphs studied.

Overall, the main objectives of this study were to (i) compare the genetic patterns in $O$. neolycopersici samples collected from tomato in different parts of Europe, North America, and Japan, including some of the isolates used in virulence tests that suggested the existence of different $O$. neolycopersici races (4); (ii) determine whether AFLP patterns in O. neolycopersici isolates are associated with the virulence phenotypes identified in a previous study (4); (iii) compare the AFLP patterns of various $O$. neolycopersici samples with those of some morphologically similar, and phylogenetically closely related, powdery mildew anamorphs collected from other plants; and (iv) carry out cross-inoculation tests with $O$. neolycopersici and closely related powdery mildew anamorphs, collected from Sedum alboroseum, C. majus, and Aquilegia vulgaris, to reveal whether they all belong to one single taxon with a wide host range or represent distinct powdery mildew fungi with restricted host ranges.

\section{MATERIALS AND METHODS}

Powdery mildew materials for molecular analyses. A total of 23 powdery mildew samples originating from different parts of the world, including 17 collected from tomato, two from common columbine (A. vulgaris), two from blue passion flower (Passiflora caerulea), one from greater celandine (C. majus), and one from striped sedum ( $S$. alboroseum), were included in the molecular study, i.e., ITS sequencing and/or AFLP analysis (Table 1). The morphology of the powdery mildew pathogens was always examined under a light microscope to verify that they were pseudoidium anamorphs, i.e., matured conidia singly, similar to $O$. neolycopersici.

DNA extraction, PCR amplification, and sequencing of the rDNA ITS region. Fungal DNA samples were prepared by collecting conidia from young and sporulating powdery mildew colonies using sterile brushes. These were washed off in eppendorf tubes containing $1 \mathrm{ml}$ of sterile water, then the conidial suspensions were centrifuged for $5 \mathrm{~min}$ at $13,000 \mathrm{rpm}$ and the supernatant was discarded. The pellets were frozen, freeze-dried, and stored at $-18^{\circ} \mathrm{C}$ until used for DNA extraction. Before centrifugation, conidial suspensions were always examined under 
a light microscope and those containing leaf trichomes were discarded to reduce the contamination of the powdery mildew samples with plant DNA. When the amount of $O$. neolycopersici conidia was low on the tomato leaf samples, these were removed with sterile brushes and used to inoculate surfacesterilized Lagenaria leucantha cv. Minibottle cotyledons maintained on mannitol sucrose agar to produce more fungal materials in vitro, as described by Bardin et al. (6), before preparing a sample for DNA extraction as described above. This procedure was not applied for powdery mildews found on hosts other than tomato.

Whole-cell DNA was extracted from the freeze-dried pellets obtained as described above using a Qiagen DNeasy Plant Mini Kit (Qiagen GmbH, Hilden, Germany) according to the manufacturer's instructions. The rDNA ITS region was amplified using the ITS1F/ITS4 fungal-specific primer pair as described in Szentiványi et al. (60). PCR products were purified using a PCRM Clean Up System (Viogene) and sequenced using a BigDye Terminator v3.1 Cycle Sequencing Kit (Applied Biosystems, Foster City, CA), according to the instructions of the manufacturer. Both strands were sequenced with the primers used for PCR amplification of the ITS region. Electrophoresis was carried out on an ABI PRISM 3100 Genetic Analyzer (Applied Biosystems, Foster City, CA).

Analyses of ITS sequence data. Sequences were compiled from electrophoregrams using Pregap4 and Gap4 (58). The obtained ITS sequences were compared with 25 sequences obtained from GenBank. Multiple alignments of the analyzed ITS sequences were obtained using MultAlin (15). The alignments were checked for ambiguities and edited using ProSeq 2.9 (17). The PAUP* 4.0b10 software package (59) was used to infer phylogenies. Modeltest 3.06 (55) was used to select the best-fit nucleotide substitution model based on Akaike information criterion (AIC) (1). The best fit model was used in the maximumlikelihood (ML) analysis using heuristic search. Also the best fit model found by Modeltest was used in the distance-based neighbor-joining $(\mathrm{NJ})$ analysis. The branches of the inferred tree were tested by bootstrap analysis with 100 and 1,000 replicates for ML and NJ analyses, respectively. The inferred trees were visualized by TreeView 1.6.6 (54) and edited using the TreeExplorer of the program Mega3.1 (37). The details of the analyses are available upon request.

DNA extraction from plant materials. Although care was taken to avoid the presence of plant cells, and especially that of leaf trichomes, when preparing powdery mildew DNA samples, the presence of plant DNA in the mildew DNA samples could not be excluded. To avoid the interference of plant DNA with fungal DNA during AFLP analyses, DNA samples extracted from mildew-free leaves of the host plants, including Lagenaria cotyledons, were also included in the AFLP work. Whole-cell DNA was extracted from leaves using the same Qiagen DNeasy Plant Mini Kit as for preparing the fungal DNA samples.

AFLP assays. Both fungal and plant DNA samples were included in the AFLP assays in order to identify bands that might have been derived from plant DNA contaminations in the powdery mildew fingerprints. Before use, the DNA concentrations of all samples were measured using a spectrophotometer (NanoDrop ND-1000, NanoDrop Technologies, Wilmington, DE). If the concentration was lower than $5 \mathrm{ng} / \mu \mathrm{l}$, the concentration was increased using SpeedVac SC100 (Savant, New York). Finally, 80 to $240 \mathrm{ng}$ of total genomic DNA was used for each sample in a final volume of $15 \mu \mathrm{l}$ in the restriction/ligation reaction of the AFLP procedure. These concentration values finally led to good quality AFLP fingerprints.

The AFLP procedure was performed as described by Vos et al. (67) with some modifications. The restriction and ligation were performed in a single step at $37^{\circ} \mathrm{C}$ for $5 \mathrm{~h}$. The genomic DNA was digested using the endonucleases EcoRI and MseI (New England BioLabs, NEB, Ipswich, MA), and the restriction fragments obtained were simultaneously ligated to EcoRI and MseI adapters (Sigma Genosys) in a total volume of $50-\mu l$ reaction mixture containing both endonucleases, 5 units each, 1 unit of T4 DNA ligase (NEB), $5 \mathrm{pM}$ EcoRI adapter, $50 \mathrm{pM}$ MseI adapter, $1 \mu \mathrm{l}$ of ATP (10 $\mathrm{mM}$ ), and $10 \mu \mathrm{l}$ of $5 \times \mathrm{RL}$ buffer (Life Technologies). The

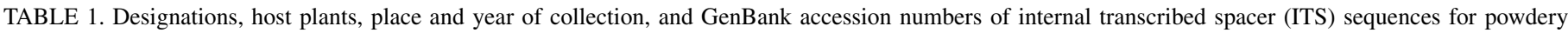
mildew samples, and molecular analyses done for each sample

\begin{tabular}{|c|c|c|c|c|}
\hline Powdery mildew samples & Host plant species and cultivar (cv.) & Place and year of collection & $\begin{array}{c}\text { GenBank accession } \\
\text { numbers of ITS sequences }\end{array}$ & $\begin{array}{l}\text { Molecular } \\
\text { analyses }\end{array}$ \\
\hline \multicolumn{5}{|l|}{$\begin{array}{l}\text { Tomato powdery mildew } \\
\text { samples }\end{array}$} \\
\hline On-04 & Solanum lycopersicum cv. Brazil & Berre, France, 2005 & EU047559 & AFLP, ITS \\
\hline On-05 & S. lycopersicum cv. Onelia & Eygalières, France, 2005 & & AFLP \\
\hline On-08 & S. lycopersicum cv. Sarnia & Salon de Provence, France, 2005 & & AFLP \\
\hline On-11 & S. lycopersicum cv. Myriade & $\begin{array}{l}\text { Saint Etienne de Saint Geoirs, } \\
\text { France, } 2005\end{array}$ & EU047560 & AFLP, ITS \\
\hline On-12 & S. lycopersicum cv. Sarnia & St Martin, France, 2005 & & AFLP \\
\hline On-16 & S. lycopersicum cv. Cameron & Francescas, France, 2005 & & AFLP \\
\hline On-17 & S. lycopersicum cv. Cigaline & Caudecoste, France, 2005 & & AFLP \\
\hline On-18 & S. lycopersicum cv. Monalbo & Montfavet, France, 2005 & EU047561 & AFLP, ITS \\
\hline On-19 & S. lycopersicum cv. Clarence & Courceroy, France, 2005 & EU047562 & AFLP, ITS \\
\hline BP-P5 & S. lycopersicum cv. Kecskeméti Jubileum & Budapest, Hungary, 1998 & EU047563 & AFLP, ITS \\
\hline BP-F1 & S. lycopersicum & Budapest, Hungary, 2005 & & AFLP \\
\hline On-Ne-1 & S. lycopersicum cv. Moneymaker & Wageningen, The Netherlands, 2004 & & AFLP \\
\hline On-Ne-2 & S. lycopersicum cv. Moneymaker & Wageningen, The Netherlands, 2006 & EU047564 & AFLP, ITS \\
\hline $\mathrm{Cz}-2$ & S. lycopersicum & Olomouc, Czech Republic, 2006 & EU047565 & AFLP, ITS \\
\hline KTP-01 & S. lycopersicum & Nara, Japan, 2005 & EU047566 & AFLP, ITS \\
\hline On-USA-1 & S. lycopersicum & Riverhead, New York, USA, 2005 & EU047567 & AFLP, ITS \\
\hline On-Ca-1 & S. lycopersicum & Harrow, Ontario, Canada, 2005 & EU047568 & AFLP, ITS \\
\hline \multicolumn{5}{|c|}{$\begin{array}{l}\text { Non-tomato powdery mildew } \\
\text { samples }\end{array}$} \\
\hline $\mathrm{Aq}-1$ & Aquilegia vulgaris & Wageningen, The Netherlands, 2005 & EU047569 & AFLP, ITS \\
\hline $\mathrm{Aq}-2$ & A. vulgaris & Debrecen, Hungary, 2006 & EU047570 & ITS \\
\hline Ch-1 & Chelidonium majus & Martonvásár, Hungary 2005 & & AFLP \\
\hline $\mathrm{Pa}-1$ & Passiflora caerulea & Wageningen, The Netherlands, 2005 & EU047571 & AFLP, ITS \\
\hline $\mathrm{Pa}-2$ & P. caerulea & Renkum, The Netherlands, 2005 & & AFLP \\
\hline $\mathrm{Se}-1$ & Sedum alboroseum cv. Mediovariegatum & Budapest, Hungary, 2006 & EU047572 & ITS \\
\hline
\end{tabular}


restriction/ligation product was diluted eight times in MilliQ water and used as a primary template of subsequent amplifications.

The pre-amplification reaction was performed using two combinations of EcoRI and MseI pre-selective primers, E01/M02 and E02/M02, each with one selective nucleotide (Table 2), in a final reaction volume of $20 \mu \mathrm{l}$ containing $5 \mu \mathrm{l}$ of the diluted primary template, $30 \mathrm{ng}$ of each pre-selective primer, $0.8 \mu \mathrm{l}$ of dNTP $(5 \mathrm{mM}), 0.4$ units of Super Taq DNA polymerase (Roche), and
$2 \mu \mathrm{l}$ of $10 \times$ Super buffer (Roche). The PCR consisted of 24 cycles, each including a denaturation step for $30 \mathrm{~s}$ at $94^{\circ} \mathrm{C}$, primer annealing for $30 \mathrm{~s}$ at $56^{\circ} \mathrm{C}$ and extension for $60 \mathrm{~s}$ at $72^{\circ} \mathrm{C}$. The pre-amplification products were verified by electrophoresis in $1 \%$ agarose gel. Products giving a smear ranging from 100 to $500 \mathrm{bp}$ were used as secondary templates for subsequent selective amplifications following $30 \times$ dilution in MilliQ water.

The selective amplifications were carried out using 19 different combinations of infrared dye (IRD)-labeled EcoRI primers (Li-

TABLE 2. Adapters, nonselective, preselective, and selective primers and their combinations used in the amplified fragment length polymorphism work

\begin{tabular}{|c|c|c|c|}
\hline Adapters and primers & Designations & Sequences & Primer combinations \\
\hline \multicolumn{4}{|l|}{ Adapters } \\
\hline EcoRI adapter & & $\begin{array}{l}\text { 5'-CTCGTAGACTGCGTACC } \\
\text { CATCTGACGCATGGTAAA-5' }\end{array}$ & \\
\hline Mse I adapter & & $\begin{array}{c}\text { 5'-GACGATGAGTCCTGAG } \\
\text { TACTCAGGACTCAT-5' }\end{array}$ & \\
\hline \multicolumn{4}{|l|}{ Nonselective primers } \\
\hline EcoRI primer & E00 & 5'-GACTGCGTACCAATTC-3' & \\
\hline MseI primer & M00 & 5'-GATGAGTCCTGAGTAA-3' & \\
\hline \multicolumn{4}{|l|}{ Preselective primers } \\
\hline \multirow[t]{2}{*}{ EcoRI primers } & E01 & $\mathrm{E} 00+\mathrm{A}$ & \multirow{3}{*}{ E01/M02, E02/M02 } \\
\hline & E02 & $\mathrm{E} 00+\mathrm{C}$ & \\
\hline MseI primer & $\mathrm{M} 02$ & $\mathrm{M} 00+\mathrm{C}$ & \\
\hline \multicolumn{4}{|l|}{ Selective primers } \\
\hline \multirow[t]{9}{*}{ EcoRI primers (IRD-labeled) } & E32 $(700 \mathrm{~nm})$ & $\mathrm{E} 00+\mathrm{AAC}$ & \\
\hline & E33 $(700 \mathrm{~nm})$ & $\mathrm{E} 00+\mathrm{AAG}$ & \\
\hline & E34 $(700 \mathrm{~nm})$ & $\mathrm{E} 00+\mathrm{AAT}$ & E32/M17, E33/M15, \\
\hline & E37 $(800 \mathrm{~nm})$ & $\mathrm{E} 00+\mathrm{ACG}$ & $\mathrm{E} 33 / \mathrm{M} 17, \mathrm{E} 33 / \mathrm{M} 18$, \\
\hline & $\mathrm{E} 41(800 \mathrm{~nm})$ & $\mathrm{E} 00+\mathrm{AGG}$ & E34/M17, E37/M18, \\
\hline & $\mathrm{E} 48(700 \mathrm{~nm})$ & $\mathrm{E} 00+\mathrm{CAC}$ & E41/M15, E41/M16, \\
\hline & $\mathrm{E} 49(700 \mathrm{~nm})$ & $\mathrm{E} 00+\mathrm{CAG}$ & $\mathrm{E} 41 / \mathrm{M} 17, \mathrm{E} 48 / \mathrm{M} 15$, \\
\hline & E54 (700 nm) & $\mathrm{E} 00+\mathrm{CCT}$ & E49/M15, E49/M16, \\
\hline & E61 $(800 \mathrm{~nm})$ & $\mathrm{E} 00+\mathrm{CTG}$ & E49/M17, E54/M17, \\
\hline \multirow[t]{4}{*}{ MseI primers (unlabeled) } & M15 & $\mathrm{M} 00+\mathrm{CA}$ & E54/M18, E61/M15, \\
\hline & M16 & $\mathrm{M} 00+\mathrm{CC}$ & E61/M16, E61/M17, \\
\hline & M17 & $\mathrm{M} 00+\mathrm{CG}$ & E61/M18 \\
\hline & M18 & $\mathrm{MOO+CT}$ & \\
\hline
\end{tabular}
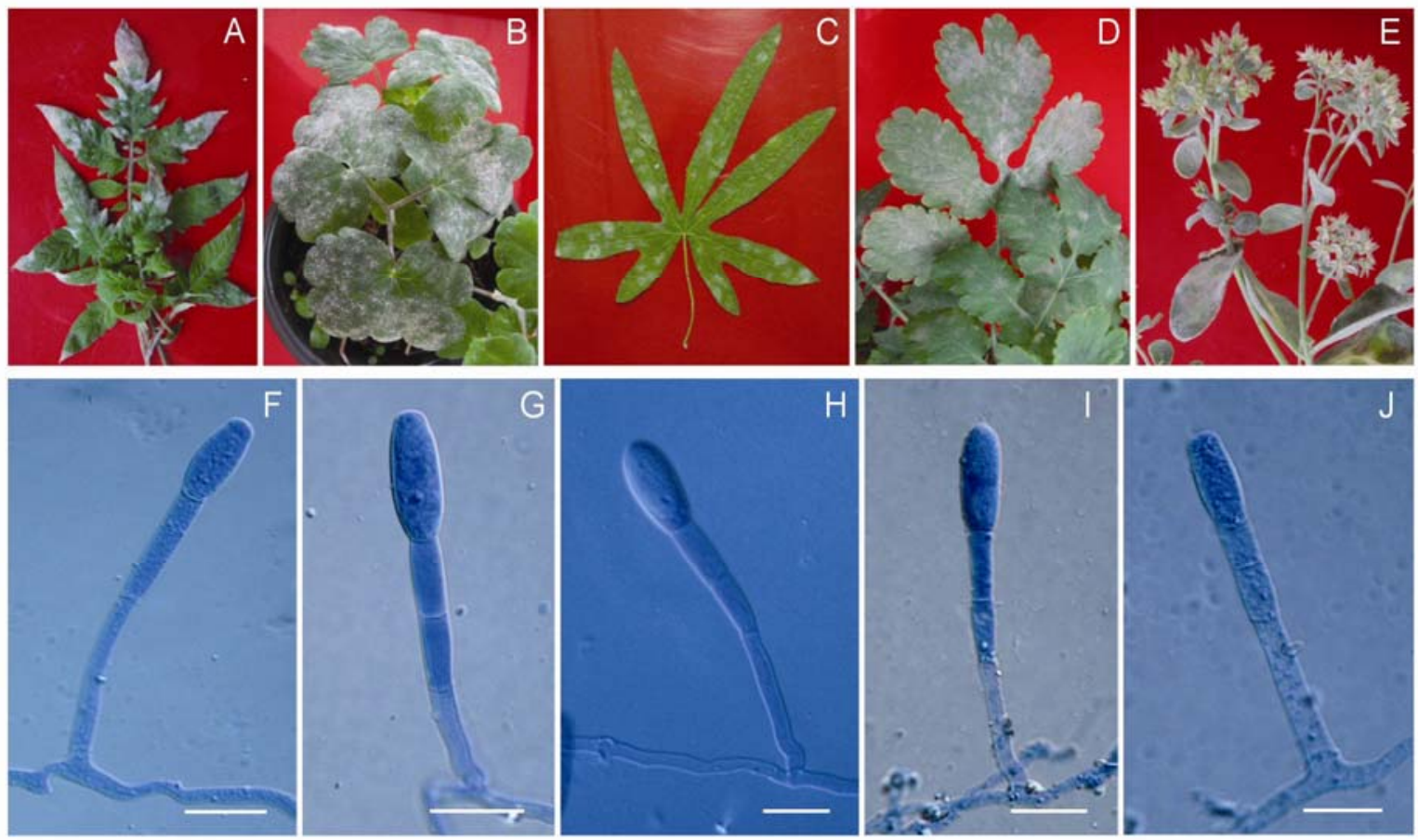

Fig. 1. Symptoms of powdery mildew infections (A to E) and micrographs of the causing powdery mildew anamorphs (F to J) examined in this study. Powdery mildew colonies on A, tomato, B, Aquilegia vulgaris, C, Passiflora caerulea, D, Chelidonium majus, and E, Sedum alboroseum. Micrograph of F, Oidium neolycopersici on tomato, G, Erysiphe aquilegiae on A. vulgaris, $\mathbf{H}$, Oidium sp. on P. caerulea, I, Oidium sp. on C. majus, and $\mathbf{J}$, Oidium sp. on S. alboroseum. Bars $=20 \mu \mathrm{m}$. Note the morphological similarities among the powdery mildew anamorphs shown in these micrographs. 
Cor Biosciences, Lincoln, NE) with three selective nucleotides each and unlabeled MseI primers (Sigma Genosys) with two selective nucleotides each. The 19 primer combinations used (Table 2) were selected after screening a total of 40 combinations (data not shown). For each PCR, the $10-\mu$ l total reaction volume consisted of $5 \mu$ of secondary template, 0.2 units of Super Taq polymerase, $1 \mu \mathrm{l}$ of $10 \times$ Super buffer, $0.4 \mu \mathrm{l}$ of dNTP $(5 \mathrm{mM}), 15 \mathrm{ng}$ of unlabeled MseI primer, and 0.5 pM IRD 700-labeled EcoRI primer or 0.6 pM IRD 800 -labeled EcoRI primer, respectively. The amplifications were carried out with a touch-down PCR profile as follows: $94^{\circ} \mathrm{C}$ for $30 \mathrm{~s}, 65^{\circ} \mathrm{C}$ for $30 \mathrm{~s}$, and $72^{\circ} \mathrm{C}$ for $60 \mathrm{~s}$, followed by 11 cycles with subsequent reduction of annealing temperature by $0.7^{\circ} \mathrm{C}$ per cycle, and continued with 24 cycles of $94^{\circ} \mathrm{C}$ for $30 \mathrm{~s}, 56^{\circ} \mathrm{C}$ for $30 \mathrm{~s}$, and $72^{\circ} \mathrm{C}$ for $60 \mathrm{~s}$. Prior to gel electrophoresis, selective amplification products were mixed with an equal volume of formamide loading buffer (98\% formamide, $10 \mathrm{mM}$ EDTA, $\mathrm{pH} 8.0,0.1 \%$ bromophenol blue) and the samples were denaturated for $5 \mathrm{~min}$ at $94^{\circ} \mathrm{C}$ and cooled on ice immediately. AFLP fragments were separated in $8 \%$ denaturing polyacrilamide gel and AFLP image data were collected automatically using a Li-Cor 4200 automated sequencer.

The reproducibility of AFLP markers was evaluated by visually comparing the fingerprints obtained from duplicate DNA samples. These were obtained from independent DNA extractions from mycelia of the same isolate. To further evaluate the reliability of AFLP markers, the whole AFLP procedure was repeated twice with a subset of three samples starting from the restriction-ligation reaction. A third evaluation of the reproducibility of AFLP markers was carried out by repeating twice all the 19 selective amplifications with a subset of another six samples. In all these repetitions, fingerprints were compared by eye.

Both powdery mildew and plant DNA samples received the same treatment during the AFLP procedure and were run side by side in all the gels to identify the bands in powdery mildew samples that might have resulted from their contamination with plant DNA.

Analyses of AFLP data. Digital AFLP images were displayed using AFLP-Quantar software package (Keygene, Netherlands) and all markers between molecular sizes of 50 to $500 \mathrm{bp}$ were scored by eye. Both the presence of monomorphic bands (present in all powdery mildew samples) and the presence/absence of polymorphic bands (absent in at least one powdery mildew sample) were considered during analyses. Markers found in both plant and powdery mildew fingerprints were excluded from the data sets.

Two binary character matrices were developed and used in subsequent analyses. The first one contained all the data collected as described above while the second one was created by excluding the presence/absence of the unique bands (identified in one single powdery mildew sample only) from the first data set. This was done to eliminate the use of data derived from possible occasional artifact AFLP bands identified in the fingerprints. The TREECON software (66) was used to create distance matrices from both data sets, based on the method of Nei and Li (50), and then to infer dendrograms using unweighted pair group method with arithmetic mean (UPGMA) and neighbor-joining (NJ) analyses. The strength of groupings was estimated using bootstrap analysis (16) with 1,000 replicates.

Plant and fungal materials and experimental design for cross-inoculation tests. Cross-inoculation experiments were carried out to test whether the phylogenetically closely related powdery mildew fungi found on tomato, C. majus, S. alboroseum, and $A$. vulgaris, could infect any of these plant species in addition to infecting their own host plants. Tomato plants, cv. Kecskeméti Jubileum, known to be susceptible to $O$. neolycopersici, were grown from seeds in pots in isolated climate chambers until four to ten fully expanded leaves developed. In addition, young potted $S$. alboroseum and A. vulgaris plants were obtained from the commerce and were kept in isolation in cabinets with controlled environment (CE) for at least 2 to 3 weeks before their use in cross-inoculation tests to ensure that they were disease free. Young C. majus plants were collected from the field in Hungary and transferred to pots in early summer, long before the natural powdery mildew epidemics started, and then kept in isolation for at least 2 to 3 weeks before used as described above.

All the cross-inoculation experiments were carried out in strict isolation in both greenhouse compartments and CE cabinets. For each experiment, one of the following plant species served as the source of mildew inoculum: tomato cv. Kecskeméti Jubileum, artificially infected with the $O$. neolycopersici strain BP-P5, maintained in the Hungarian institute (34) and used in previous works (4), as well; C. majus, naturally infected with Oidium sp. when collected from the field in Hungary; S. alboroseum cv. Mediovariegatum, naturally infected with Oidium sp. when purchased from growers in Hungary; and A. vulgaris naturally infected with the respective Oidium sp. when collected from a garden in the Netherlands. In subsequent experiments, C. majus, $S$. alboroseum, and A. vulgaris plants infected artificially with their original powdery mildew pathogens (when serving as positive controls in cross-inoculation tests) were also used as sources of inoculum. The powdery mildew fungus found on P. caerulea in two places in the Netherlands, and used in both the ITS and the AFLP analyses (Table 1), was not included in the cross-inoculation tests because it was not possible to maintain it in the greenhouse. However, young, mildew-free cuttings obtained from the $P$. caerulea individual that served as the source of the Pa-1 sample were tested for their susceptibility to the other four powdery mildews studied. These were rooted in water and then transferred to pots and kept in isolation for at least 2 to 3 weeks before use.

Each cross-inoculation experiment started by placing one to four pots with plants infected with their original powdery mildew pathogen (the source of inoculum) in close vicinity of potted, mildew-free plants (test plants), representing the hosts of closely related Oidium spp. Two to four pots were used for each test plant species. Mildew-free individuals of the plant species serving as the source of inoculum served as positive controls. All the test plants were inoculated by touching their leaves to powdery mildew colonies growing on the infected plants, in addition to being placed close to them. All these plants were kept together in strict isolation in either a greenhouse compartment or a $\mathrm{CE}$ cabinet for at least 3 weeks. As negative controls, two pots of mildew-free individuals for each plant species were kept in the same place under cover, without inoculations. Each experimental setup (using tomato, C. majus, S. alboroseum, and A. vulgaris in rotation as sources of inoculum) was repeated at least two to five times in both CE cabinets and greenhouse compartments in 2005 and 2006 in summer and autumn. A 16-h daily, artificial illumination was applied in the $\mathrm{CE}$ cabinets and the natural daily illumination was supplemented with $2 \mathrm{~h}$ artificial light/day in the greenhouse compartments in autumn. The temperature was always kept between 18 to $24^{\circ} \mathrm{C}$ and the relative humidity between 70 to $90 \%$ in both facilities.

Three weeks after inoculation, test plants were visually examined for the presence of powdery mildew colonies. If found, the identity of the pathogens was confirmed by sequencing the ITS region as described above. Also, test plants infected in crossinoculation experiments with a powdery mildew different from their original mildew pathogen were used as sources of inoculum in a subsequent experiment to verify whether the respective mildew pathogen can infect again its original host plant species.

Another set of cross-inoculations was also carried out to test the polyphagous nature of $O$. neolycopersici reported in some works $(39,68)$. Eggplant, cv. Kecskeméti Lila, tobacco, cv. Xanthi, and four tobacco accessions (nos. 904750309, 904750304, 904750160, and 944750092) used by Huang et al. (24), two 
commercial varieties of soybean, P. xhybrida cv. Wave Blue, and wild-type Arabidopsis thaliana were grown from seeds as described previously for tomato plants and then were inoculated with $O$. neolycopersici strain BP-P5. All the details of the experimental design followed the protocol described above.

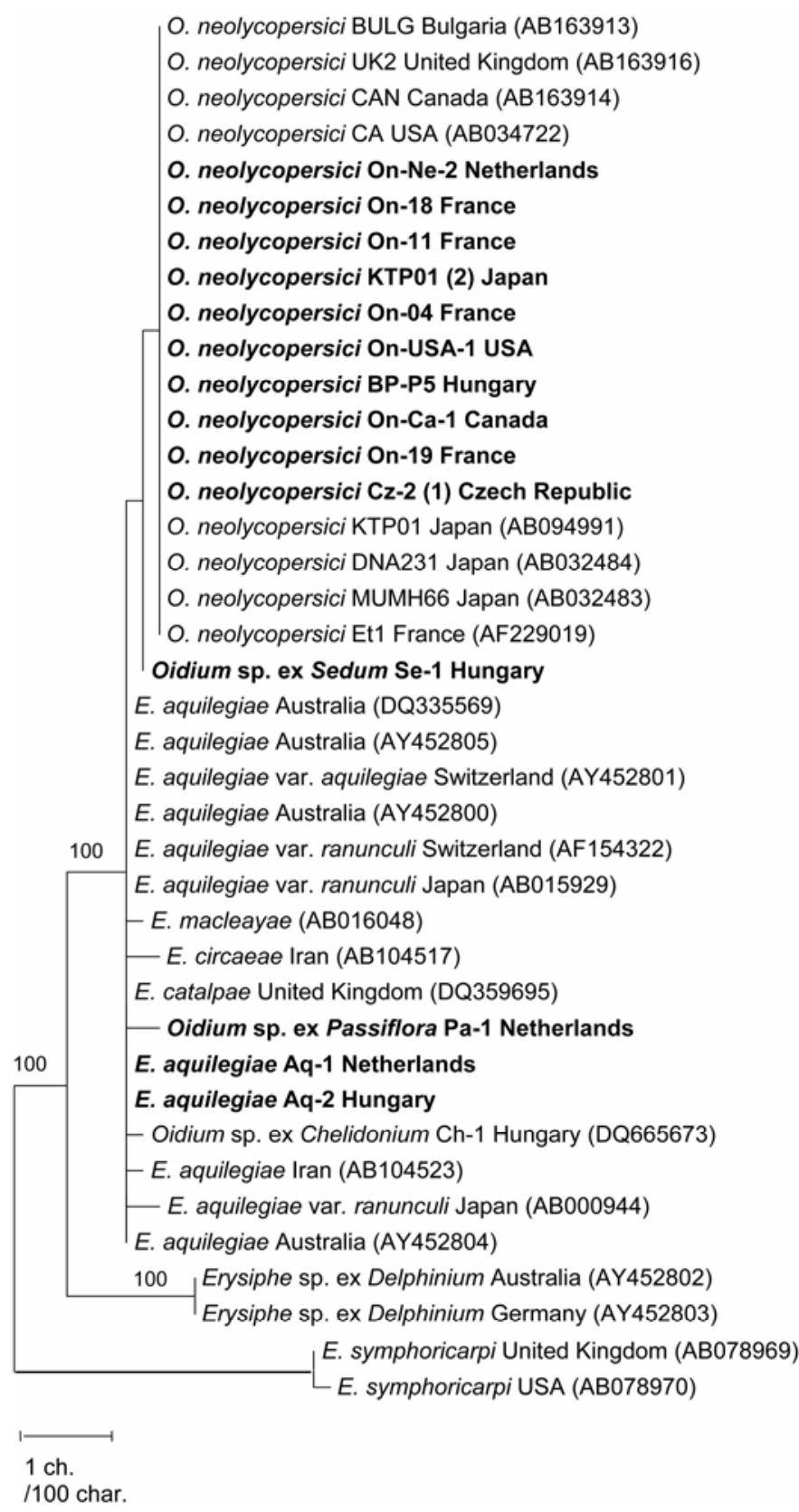

Fig. 2. The maximum-likelihood tree of the internal transcribed spacer (ITS) sequences of 39 powdery mildew specimens with two Erysiphe symphoricarpi (AB078970 and AB078969) sequences as outgroup, inferred from PAUP* $4.0 \mathrm{~b} 10$ software package (59). Fourteen ITS sequences out of 39, shown in bold, were determined in this study. GenBank accession numbers of the sequences from earlier studies are shown in brackets. The gaps in the 552 characters long alignment were handled as missing characters. The TVM+I model was used as the best- $\bullet$ model based on the AIC results of the software Modeltest 3.06 (55). The base frequencies were: $\mathrm{A}=0.2031, \mathrm{C}=0.2662, \mathrm{G}=$ $0.2765, \mathrm{~T}=0.2542$; the values of the rate matrix $(\mathrm{rAC}, \mathrm{rAG}, \mathrm{rAT}, \mathrm{rCG}$, rCT, rGT) were $3.3740,5.4222,3.5420,0.3369,5.4222$, and 1.0000, respectively; the rate of the invariable site was 0.6355 . Bootstrap values were obtained from 1,000 replicates, values higher than $75 \%$ are indicated as percentages on the branches. Bar $=1$ changes on 100 character. The geographical origins of the powdery mildew samples sequenced in this study are shown in Table 1.

\section{RESULTS}

Pseudoidium anamorphs on tomato and other plants. Light microscopy confirmed that all the powdery mildew anamorphs, collected from tomato, A. vulgaris, C. majus, P. caerulea, and $S$. alboroseum, matured their conidia singly and exhibited other morphological characteristics diagnostic for Oidium subgenus Pseudoidium sensu Cook et al. (14), as well. Conidial pseudochain formation was sometimes observed in these pseudoidiums as reported in some works $(34,53)$. The sexual stage of these fungi was not observed, except for the one infecting A. vulgaris. Based on morphological characteristics, the anamorphs found on hosts other than tomato were indistinguishable from $O$. neolycopersici collected from tomato (Fig. 1). The powdery mildew collected from A. vulgaris was identified as E. aquilegiae based on Braun (8), while the anamorphs infecting C. majus, S. alboroseum, and $P$. caerulea were referred to as Oidium spp. in this study, similar to earlier works $(26,27)$, because no species names could be assigned to these fungi to date.

ITS sequence analyses. The ITS sequences were determined in a total of $10 \mathrm{O}$. neolycopersici samples representing different parts of Europe, North America, and Japan, and also in two powdery mildew samples collected from A. vulgaris, one from $P$. caerulea, and another one from S. alboroseum. A 552-character long alignment of 39 ITS sequences was used in the phylogenetic analyses. The TVM+I model was used as the best- $\bullet t$ model based on the AIC. Using this model, the distance-based NJ and ML analyses resulted in the same phylogenetic trees with approximately the same bootstrap supports of the branches. The $O$. neolycopersici, E. aquilegiae, E. macleayae, E. circaeae, E. catalpae, and the Oidium spp. infecting $S$. alboroseum, $P$. caerulea, and $C$. majus, respectively, grouped together with strong bootstrap support (Fig. 2). The sequences of the O. neolycopersici strains with different geographic origin were identical and formed a group with moderate support within this clade. The ITS sequences of the remaining taxa in this clade differed in one or a few nucleotides; however, no further subgroups separated within the clade. A comparison of the ITS sequences of the powdery mildews included in our cross-inoculation experiments and/or AFLP analysis revealed differences in 1 to 5 single nucleotide positions across the ITS region (Fig. 3). To ensure that none of these differences resulted from errors that might occur during the PCRs and/or the sequencing reactions, all the electrophoregrams of the ITS sequences determined in this work were carefully examined. In addition to being used in the phylogenetic analysis, these ITS sequences served as a basis for the precise identification of morphologically indistinguishable anamorphs found on different host plants in cross-inoculation tests. Thus, all the ITS sequences were determined several times in this work.

Cross-inoculation experiments. All the extensive cross-inoculation tests were carried out in both greenhouse compartments and $\mathrm{CE}$ cabinets, and repeated three to six times. None of the powdery mildew fungi collected from and maintained on $C$. majus, $S$. alboroseum, and $A$. vulgaris were able to infect any of the plant species tested (tomato, A. vulgaris, C. majus, P. caerulea, and $S$. alboroseum) aside from their original hosts. O. neolycopersici differed from these fungi because it was able to infect $S$. alboroseum in addition to tomato in all the tests (Table 3). Inoculations of powdery mildew-free tomato plants with conidia of $O$. neolycopersici produced on $S$. alboroseum resulted in disease symptoms on its original host. This confirmed that $O$. neolycopersici was able to infect one more plant species, following artificial inoculations, in addition to its original host. The ITS sequences that were routinely determined in powdery mildews that appeared on the tested plants in cross-inoculation tests always confirmed the identity of the pathogens. All the control plants used in cross-inoculation tests remained powdery mildew-free which suggests that our isolation methods used in both green- 
house compartments and CE cabinets did not allow the unwanted spread of inocula to plants other than those inoculated artificially in these tests. The Oidium sp. infecting P. caerulea was not included in these cross-inoculation tests because it was not possible to maintain it in the greenhouse. Disease-free cuttings from a susceptible $P$. caerulea plant were included in all the tests but none of the powdery mildew pathogens included in this study was able to infect them (Table 3).

To test further the polyphagous nature of O. neolycopersici, revealed by the infection of $S$. alboroseum in this work, tobacco, eggplant, soybean, petunia, and A. thaliana, grown from seeds in isolation, were inoculated with isolate BP-P5 as previously described. Soybean plants were completely resistant to this isolate of $O$. neolycopersici in our tests. Wild-type A. thaliana, and petunia $\mathrm{cv}$. Wave Blue, were susceptible, while tobacco and eggplant were only moderately susceptible because most of the $O$. neolycopersici colonies that developed on their leaves remained localized with sparse sporulation.

AFLP analysis. All the powdery mildew samples of this study, collected from various host plants, were included in the initial steps of the AFLP work. After screening a subset of mildew samples with 40 AFLP primer combinations (PCs, data not shown), 19 PCs were selected and used in the subsequent analysis (Table 2). Among powdery mildew samples, a total of 17 collected from tomato, two from P. caerulea, one from C. majus, and another one from $A$. vulgaris were selected for the complete AFLP work (Table 1) based on the quality of their DNA.

The 19 selected PCs (Table 2) yielded a total of 1,119 AFLP markers (30 to 93 per PC). Out of these, 1,094 (97.77\%) were polymorphic and only 25 were monomorphic for all samples. In DNA samples of $O$. neolycopersici analyzed, a total of 747 markers were identified that included 589 polymorphic and 158 monomorphic markers. Each powdery mildew sample obtained from either tomato or other hosts exhibited unique AFLP finger-

\begin{tabular}{|c|c|c|c|c|c|c|c|}
\hline & \multicolumn{7}{|c|}{ Nucleotide positions with variable characters* } \\
\hline & $\overline{32}$ & 90 & 122 & 347 & 356 & 393 & 447 \\
\hline o. neolycopersici** & G & - & $\mathrm{T}$ & $\mathrm{T}$ & - & G & $\mathrm{T}$ \\
\hline E. aquilegiae & G & - & c & $\mathrm{T}$ & - & G & c \\
\hline Oidium sp. on C. majus & G & c & c & A & G & G & c \\
\hline Oidium sp. on $P$. caerulea & A & - & c & $\mathrm{T}$ & - & A & c \\
\hline Oidium sp. on $S$. alboroseum & G & - & c & $\mathrm{T}$ & - & G & $\mathrm{T}$ \\
\hline \multicolumn{8}{|c|}{$\begin{array}{l}\text { *Nucleotide positions in the ITS region were numbered starting } \\
\text { with the first position in the ITS1 sequence. } \\
{ }^{*} \text { All the ITS sequences were identical in several samples. }\end{array}$} \\
\hline
\end{tabular}

Fig. 3. Single nucleotide positions with variable characters detected in the internal transcribed spacer (ITS) sequences of Erysiphe aquilegiae and Oidium spp., infecting Chelidonium majus, Passiflora caerulea, and Sedum alboroseum, respectively, when compared to that of $O$. neolycopersici. Letters shown in bold are nucleotides different from those in the ITS sequence of $O$. neolycopersici in the same position. All the sequences included in this analysis were determined several times in different DNA samples. prints, thus each represented a unique genotype (Fig. 4). A total of 448 unique bands, each present in one single powdery mildew sample only, were identified (Table 4). The number of unique bands was, in general, higher in non-tomato mildew samples than in $O$. neolycopersici specimens probably because only one or two powdery mildew samples coming from A. vulgaris, $C$. majus, and $P$. caerulea were included in the AFLP work.

The reproducibility of the AFLP fingerprints was verified by including duplicate DNA samples for two selected isolates, KTP01 and $\mathrm{Cz}-2$, respectively, in the AFLP analysis. These represented different DNA extractions from the same specimen. The duplicates yielded the same AFLP patterns with all PCs, except a total of two bands present in only one DNA sample for KTP-01 and another two bands identified in only one DNA sample for Cz2 (Table 4). This finding indicated that more than $95 \%$ of the unique bands were reproducible in this work. Among tomato powdery mildew samples, the Japanese isolate KTP-01 had the highest number of unique bands, a total of 60 bands that were not found in any other powdery mildew sample (Table 4). These all were found in both duplicates of KTP-01, except those two bands that were identified in only one of the DNA samples for this isolate.

Two data sets were created for genetic distance analyses. The first one contained all the 1,119 fungal markers and the second one was created by excluding the presence/absence of the 448 unique fungal markers from the first data matrix. Thus, the reduced data set consisted of 671 fungal markers that were identified in at least two powdery mildew samples. Both $\mathrm{NJ}$ and UPGMA analyses gave similar results for both data matrices, except for the pairings of the most closely related samples. Figure 4 shows an NJ tree based on the reduced data matrix.

The AFLP data clearly differentiated the O. neolycopersici samples from the other, phylogenetically closely related powdery mildew fungi collected from $C$. majus, $A$. vulgaris, and $P$. caerulea. Within the $O$. neolycopersici group, the similarities were not clearly associated with the geographical origin of the samples except for the two Hungarian isolates, BP-P5 and BP-F1, and the two Dutch isolates, On-Ne-1 and On-Ne-2, that were isolated in different years in the same places, in Budapest and Wageningen, respectively (Table 1). Nine closely similar European isolates clustered together with those originating from North America and Japan. However, the North American and the Japanese isolates were somewhat distant from both each other and the nine European samples. Four other isolates, On-05, On-08, On-11, and On12 , collected in the south-eastern region of France, formed another distinct subgroup, while another sample, On-19, obtained from the northern part of France, was distinct from all the other $O$. neolycopersici samples (Fig. 4). The pair-wise genetic distances among the samples collected in France, the country where most of the samples originated, ranged from 0.03 to 0.33 , while those for all samples of $O$. neolycopersici ranged from 0.03 to 0.35 . The ITS sequences of representatives of all these O. neolycopersici subgroups were identical (Fig. 2).

Although the number of non-tomato powdery mildew samples, collected from $C$. majus, A. vulgaris, and $P$. caerulea was very low in this work, the AFLP analysis clearly differentiated them from each other, and also from $O$. neolycopersici. The two

TABLE 3. Results of cross-inoculation experiments repeated two to five times in isolation in both cabinets with controlled environment and greenhouse compartments

\begin{tabular}{lccccc}
\hline Plant species tested & Oidium neolycopersici & Erysiphe aquilegiae & $\begin{array}{c}\text { Oidium sp. on } \\
\text { P. caerulea }\end{array}$ & $\begin{array}{c}\text { Oidium } \text { sp. on } \\
\text { C. majus }\end{array}$ & $\begin{array}{c}\text { Oidium } \text { sp. on } \\
\text { S. alboroseum }\end{array}$ \\
\hline Solanum lycopersicum & + & - & ND $^{\mathrm{a}}$ & - & - \\
Aquilegia vulgaris & - & + & $\mathrm{ND}$ & - & - \\
Passiflora caerulea & - & - & + & - & + \\
Chelidonium majus & - & - & ND & - & + \\
Sedum alboroseum & + & - & ND & - \\
\hline
\end{tabular}

a $\mathrm{ND}=$ not determined. 
samples coming from $P$. caerulea, collected in two Dutch localities $\approx 8 \mathrm{~km}$ apart, were more similar than those coming from other host plants. There were clear differences between the tomato and the non-tomato powdery mildew samples because the analysis of the reduced AFLP data set (Fig. 4), created after the exclusion of the unique bands, lead to the same grouping as the analysis of the original data matrix (data not shown). Pair-wise comparisons of the AFLP bands revealed that the tomato and the non-tomato isolates shared only 10 to $40 \%$ of the total number of bands while these values were 45 to $93 \%$ between pairs of the 17 $O$. neolycopersici isolates. The relatively high number of unique bands in the four non-tomato samples (Table 4), in addition to the low number of monomorphic markers, also indicated a low similarity between these fungi and $O$. neolycopersici. The powdery mildew fungi collected from $C$. majus, A. vulgaris, and $P$. caerulea differed in 1 to 5 single nucleotide positions in the ITS region from $O$. neolycopersici (Fig. 3) and our cross-inoculation experiments indicated that their host ranges were also different (Table 3).

\section{DISCUSSION}

In $O$. neolycopersici, only asexual reproduction is known; the sexual stage, i.e., the formation of ascomata with viable ascospores, has never been reported and experimental trials to produce these structures at least in vitro, after mating different pairs of isolates, failed (34). However, all the 17 tomato powdery mildew samples included in this work exhibited unique AFLP profiles, indicating different genotypes. This was found even when a conservative approach was applied in the analysis of AFLP bands, i.e., when the unique bands (Table 4) were excluded from the data set used in the final analysis (Fig. 4). The high genotypic diversity might suggest the existence of either a yet unrevealed sexual reproduction or other genetic mechanisms that create a relatively high genetic variation in $O$. neolycopersici. However, genotype diversity was much higher among tomato powdery mildew isolates collected in a more restricted area, in France, than among other European, American, and Japanese isolates (Fig. 4). This indicates that the number of samples included in this study is not sufficient for a meaningful analysis of the overall genetic diversity in $O$. neolycopersici.

In anamorphic powdery mildew species, such as $O$. neolycopersici, the existence of a yet unknown sexual stage should always be taken in consideration when dealing with intra-specific genetic diversity. Several powdery mildew species are known to reproduce only, or predominantly, asexually for at least several decades before starting to produce the sexual stage in certain environments. This is particularly valid for invasive populations of some powdery mildew species that have recently increased their host ranges or geographical areas and caused previously unknown plant diseases in new environments $(32,33)$. For example, the grapevine powdery mildew pathogen, E. necator (syn. Uncinula necator), did not produce the sexual stage for decades in Europe, after being introduced there from North America in the 19th century (12). This has also happened during the first period of the European spread of E. symphoricarpi on snowberry, thought to be native to North America (33), and that of E. arcuata on hornbeam, thought to be introduced from Asia (10). In the meantime, there was no loss of the sexual reproduction in the native areas of any of these three species $(10,12,33)$. These examples show that at least some powdery mildew populations can rapidly spread and occupy new geographical areas, or infect new host plant species (65), even in the absence of the sexual stage. However, nothing is known about the genetic structure of these invasive populations. Clearly, detailed population analyses are needed to assess the genetic diversities in these, and other, apparently clonal, and invasive, fungal populations that are often perceived as genetically (near-) identical clones $(42,47)$.

One of the goals of the present AFLP analysis was to determine whether AFLP profiles in $O$. neolycopersici isolates might be

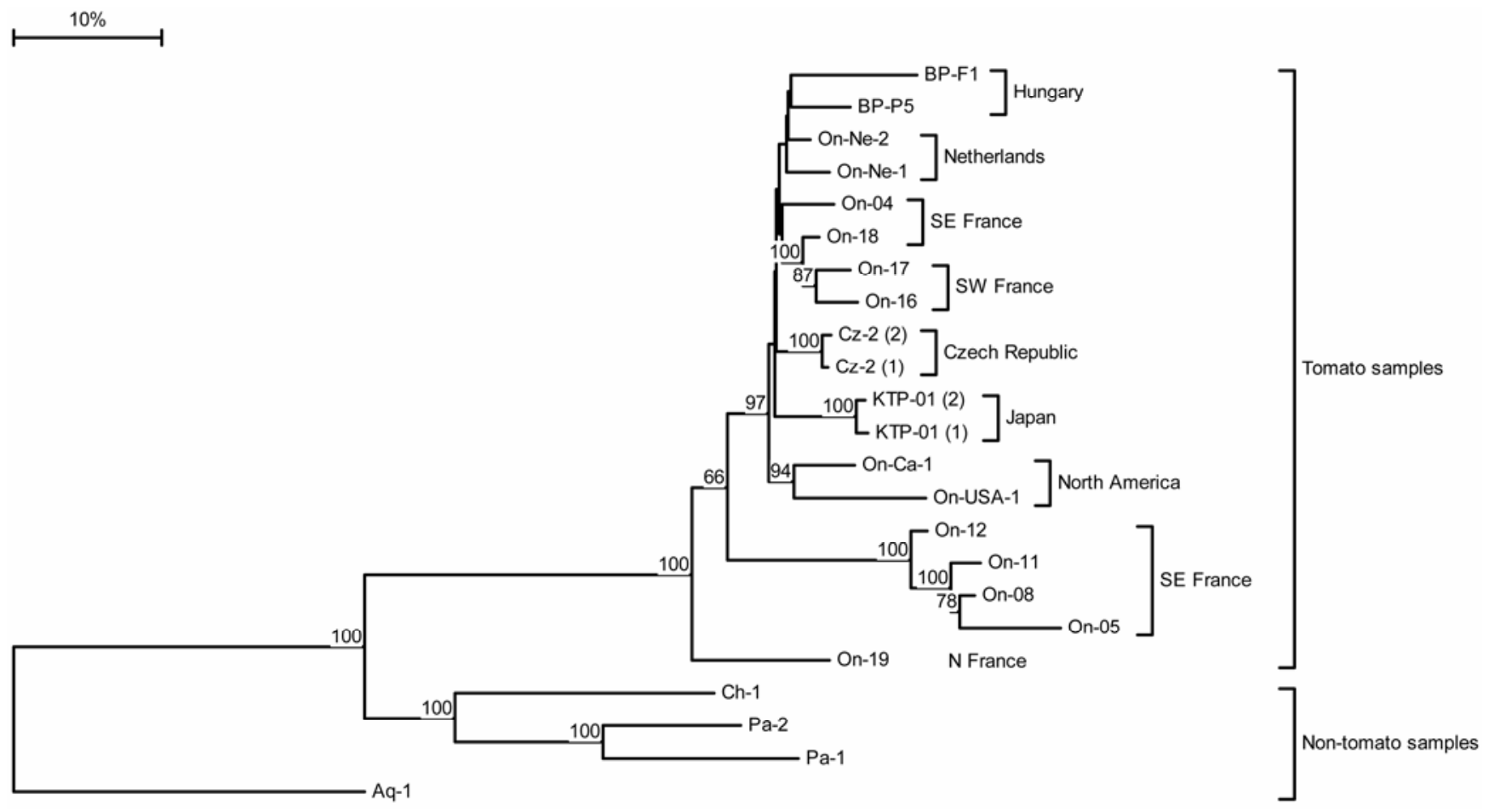

Fig. 4. A dendrogram showing the genetic distances among 17 tomato powdery mildew samples and four non-tomato powdery mildew samples computed using the TREECON software (66) based on a reduced set of amplified fragment length polymorphism (AFLP) bands. This consisted of 671 markers and was created after the exclusion of the unique bands (Table 4) from the original AFLP data set. Genetic distances were determined based on the method of Nei and Li (50) and are shown based on a neighbor-joining (NJ) analysis. The strength of groupings was estimated using bootstrap analysis $(16)$ with 1,000 replicates and values $\geq$ $50 \%$ are indicated as percentages on the branches. Bar=10\% genetic distance. The host plants and geographical origins of the samples are shown in Table 1 . DNA samples Cz-2 (1) and Cz-2 (2) and KTP-01 (1) and KTP-01 (2) are duplicates from isolates Cz-2 and KTP-01, respectively. 
associated with the virulence patterns identified in a previous study (4). However, no clear correlation was found between the virulence and the AFLP patterns of the $O$. neolycopersici isolates studied. For example, the Czech isolate, $\mathrm{Cz}-2$, that had overcome the major resistance genes $\mathrm{Ol}-4$ and $\mathrm{Ol}-6$ (4), clustered together with isolates BP-P5 and On-Ne-2 (Fig. 4) known to be suppressed by these resistance genes (4). Also, the Japanese isolate KTP-01, reported to infect the tomato cultivar Grace, which is resistant to some European and American O. neolycopersici populations (30), grouped together with some European and American isolates. However, this isolate was somewhat distant from the others in the first sub-group (Fig. 4) and exhibited the highest number of unique bands within the tomato powdery mildew samples (Table 4). Although the French isolates that also infected cv. Grace (63) were not included in this work, interestingly, four (On-04, On-16, On-17, and On-18) out of the nine French isolates analyzed clustered together with KTP-01. Overall, our AFLP analysis did not provide clear molecular evidence for the differences in the virulence of various $O$. neolycopersici isolates. Furthermore, the close similarity between the AFLP profiles of the three isolates, BP-P5, On-Ne-2, and Cz-2, which exhibited different virulence patterns in a previous study (4), suggests that changes in virulence of $O$. neolycopersici are associated with very limited changes in genomic sequences. Other studies on Fusarium oxysporum f. sp. cubense isolates (20) and on Mycosphaerella pinodes isolates (71) also revealed an absence of correlation between AFLP groupings and virulence. In Verticillium albo-atrum isolates, however, a clear correlation was found between AFLP patterns and virulence on hop (Humulus lupulus) (56).

The low number of non-tomato mildew samples limited the value of the AFLP analysis in these samples. However, the results of the cross-inoculation experiments (Table 3), together with the analysis of the ITS sequences (Figs. 2 and 3) and AFLP patterns (Fig. 4) indicate that the powdery mildew anamorphs collected from A. vulgaris, C. majus, P. caerulea, and S. alboroseum all represent distinct, but closely related taxa. This conclusion is jointly supported by all the results obtained in this work, although the anamorph infecting $S$. alboroseum was not included in the AFLP work and the one infecting $P$. caerulea could not be used in the cross-inoculation tests. Interestingly, the isolates Ch-1 from C. majus, Pa-1 from P. caerulea and Aq-1 from A. vulgaris were collected in places where a part of the $O$. neolycopersici samples also came from (Table 1).

Ideally, cross-inoculation tests should include a substantial number of different plant genotypes (and not just one) in order to decide whether a plant species is a host or a nonhost (51). The number of plant genotypes/species used in our tests was limited by the accessibility of $P$. caerulea and $S$. alboroseum materials and also by practical considerations. In spite of these limitations, our cross-inoculations provided important data for the host range of $O$. neolycopersici and other Oidium spp. The susceptibility of wild-type $A$. thaliana plants to $O$. neolycopersici, reported by Xiao et al. (70), and that of petunia, reported in some papers $(18,29,68)$, was confirmed in our tests. In contrast, we found only localized sporulation of $O$. neolycopersici on eggplant, cv. Kecskeméti Lila, and also on tobacco, although Huang et al. (24) reported intense sporulation of the pathogen on the same tobacco accessions tested. Other works reported that some cultivars and breeding lines of tobacco $(18,24,29,38)$ and eggplant $(18,24$, 38,68 ) were susceptible to tomato powdery mildew while some others were resistant $(29,39)$. The apparent contradictions between the results of different artificial inoculations, carried out in different laboratories, could result from many factors, as discussed by Niks (51).

Several comprehensive analyses showed that ITS sequences always differ in at least one or a few nucleotides in specimens considered as belonging to different taxa on the basis of morphology and/or host range $(23,25,49,57,62)$, while those determined in powdery mildew samples collected from the same host plant species were identical $(21,22,35)$. There is no doubt that the use of ITS sequences in analyzing phylogenetic relationships in closely related fungal taxa in general, and in closely related powdery mildew fungi in particular, has some limitations $(45,69)$. In spite of these limitations, the rDNA ITS region is currently the

TABLE 4. Number of unique bands (bands detected in the fingerprint of one single powdery mildew isolate only) identified during amplified fragment length polymorphism analysis ${ }^{\mathrm{a}}$

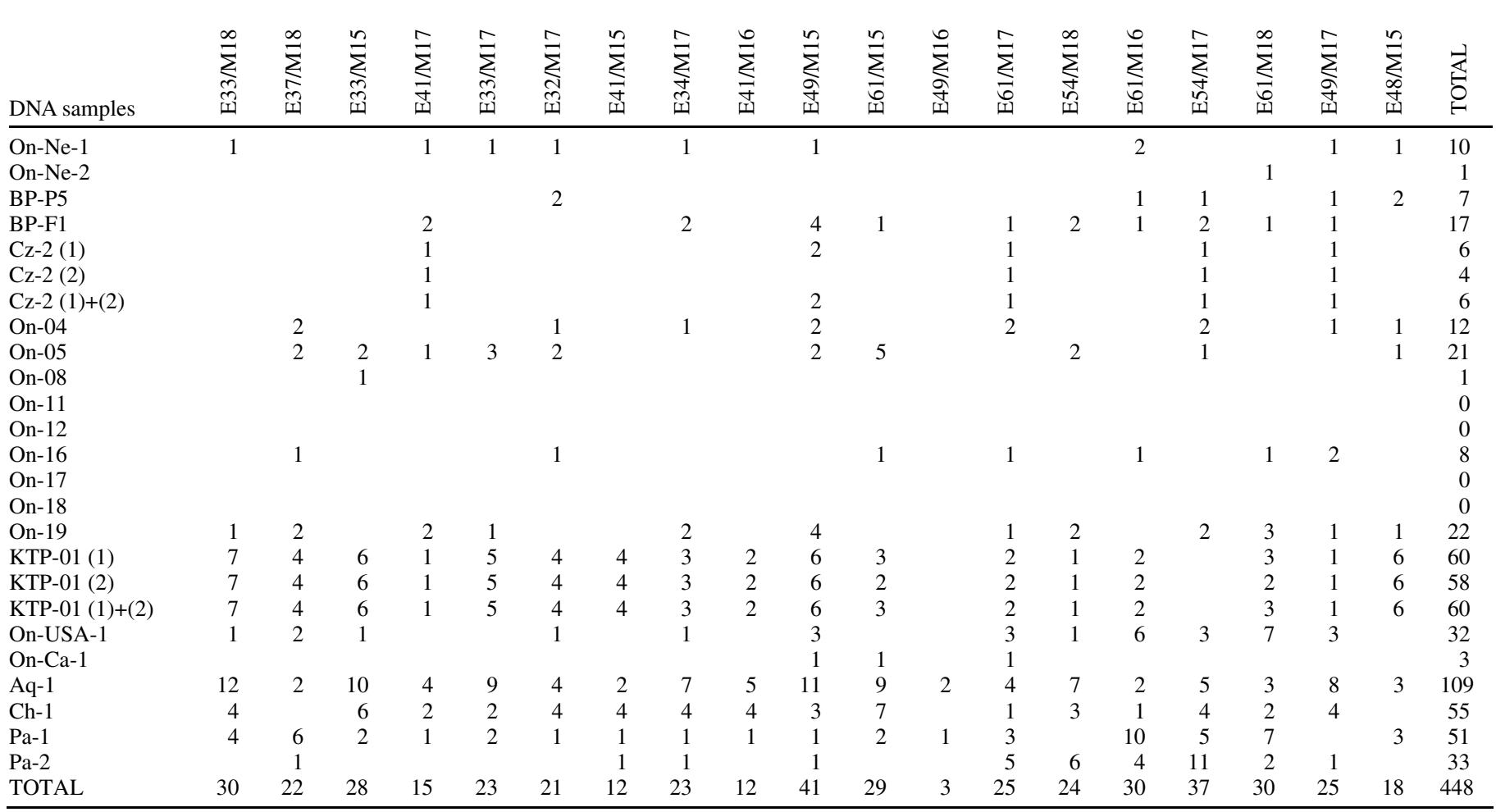


best characterized part of the genome in the Erysiphales and has been used in several comprehensive phylogenetic and molecular taxonomic works which have never led to results that are in contradiction with those based on morphological and/or host range data $(13,21,23,25,46,49,62)$. However, this is the first genome-wide study that investigates the relationships among powdery mildews that are closely related based on ITS sequences and morphology. Thus, this study tested for the first time the value of ITS data in delineating closely related taxa in the Erysiphales. The joint use of cross-inoculation experiments, ITS sequence analyses, and AFLP analyses have led to mutually supporting results because all the results revealed clear differences among $O$. neolycopersici, E. aquilegiae, and the anamorphs collected from C. majus, $P$. caerulea, and $S$. alboroseum. This suggests that all these pathogens represent distinct but closely related species of the Erysiphales according to the phylogenetic species recognition $(19,61)$. Among these fungi, the Oidium spp. found on C. majus and $S$. alboroseum, respectively, have only recently been reported in the literature $(26,27)$.

All the results obtained in this work showed that ITS sequences are indeed valuable in the identification of distinct powdery mildew lineages that should be recognized as different taxa in taxonomic works. A total of 18 specimens of $O$. neolycopersici, collected in different parts of the world (Table 1), exhibited identical ITS sequences (Fig. 2). Some of these were determined in previous studies $(29,34,36)$. To our knowledge, within the Erysiphales, $O$. neolycopersici is the species with the highest number of specimens in which the ITS sequences were determined. The fact that they are identical in 18 different specimens supports the value of ITS data in powdery mildew identification. Also, the one to five nucleotide differences between the ITS sequence of $O$. neolycopersici and those of the powdery mildew fungi collected from A. vulgaris, C. majus, P. caerulea, and $S$. alboroseum (Fig. 3) clearly shows that distinct powdery mildew species with similar morphology but different host ranges and genome-wide patterns, such as AFLP polymorphism, can reliably be distinguished based on their ITS sequences. A difference in only one or two single nucleotide positions in the ITS sequence could indicate considerable differences between two powdery mildew specimens in terms of their host range and genome-wide patterns. For example, E. aquilegiae and $O$. neolycopersici differ in only two nucleotide positions in their ITS region (Fig. 3). This difference, however, reflects major differences in (i) their host ranges, as they do not infect each other's host plants (Table 3), (ii) their genomes (Fig. 4), and (iii) their reproduction, as E. aquilegiae regularly produces ascomata, the sexual fruiting bodies, even on our experimental plants in the greenhouse, while $O$. neolycopersici does not. These differences highlight the importance of determining the ITS (and any other) DNA sequences with maximum care. Unfortunately, as pointed out by some authors $(2,11)$, a number of rDNA sequences deposited in public databases are unreliable for various reasons. There are three ITS sequences deposited in GenBank for $O$. neolycopersici (GenBank accession nos. AF171876, AF229015, and AB163915) which are only $99 \%$ similar to the 18 identical sequences used in this work. These three sequences were not used in our analysis because we could not exclude the possibility that the differences resulted from sequencing errors.

$O$. neolycopersici is recognized as a well-defined anamorphic powdery mildew species in this study. The analyses of ITS sequences and AFLP patterns, supplemented with host range data, indicate that $O$. neolycopersici clearly differs from morphologically similar and phylogenetically closely related anamorphs, such as those included in this work. This means that the powdery mildews found on A. vulgaris, C. majus, P. caerulea, and S. alboroseum do not serve as sources of inoculum for tomato powdery mildew epidemics. However, in our cross-inoculation tests, $O$. neolycopersici was able to infect $S$. alboroseum, petunia, and wild-type $A$. thaliana, and, to some extent, eggplant and tobacco, as well. These results suggest a somewhat polyphagous nature of $O$. neolycopersici. Host range expansion is one of the major evolutionary processes in the Erysiphales $(46,62)$, and such an event has recently been documented in a species infecting Arabidopsis and other plants (65). Thus, the possibility of detecting $O$. neolycopersici on plants other than tomato in the field cannot be excluded.

The morphology and the ITS sequences of the powdery mildew anamorphs included in this study are very similar but each are pathogenic to plant species belonging to different plant families. This suggests that during the evolution of this group of the Erysiphales, host range expansions should have occurred across plant families, eventually followed by segregations of the populations established on different host plant species. This hypothesis is supported by the observation that in artificial cross-inoculation tests, $O$. neolycopersici infected two nonsolanaceous plant species, S. alboroseum and A. thaliana, of which the former one points to the Oidium sp. collected from $S$. alboroseum and proved to be closely related to $O$. neolycopersici in this work (Fig. 2). However, the natural occurrence of $O$. neolycopersici has been demonstrated only on tomato to date, so its role in powdery mildew epidemics on plants other than tomato cannot be proven so far.

\section{ACKNOWLEDGMENTS}

The authors thank M. L. Daughtrey, R. Cerkauskas, and A. Lebeda for providing tomato powdery mildew samples and to $\mathrm{C}$. Troulet for excellent technical assistance in the culture of powdery mildew samples. An anonymous reviewer's valuable comments are also greatly appreciated. The support of a József Öveges grant of the Hungarian National Office for Research and Technology (NKTH), awarded to L. Kiss, and that of a János Bolyai Research Fellowship and a postdoctoral research grant of the Hungarian Research Fund (OTKA, D048333), both awarded to G. M. Kovács, are also acknowledged.

\section{LITERATURE CITED}

1. Akaike, H. 1974. A new look at the statistical model identification. IEEE Trans. Autom. Contr. 19:716-723.

2. Ashelford, K. E., Chuzhanova, N. A., Fry, J. C., Jones, A. J., and Weightman, A. J. 2005. At least 1 in 20 16S rRNA sequence records currently held in public repositories is estimated to contain substantial anomalies. Appl. Environ. Microbiol. 71:7724-7736.

3. Bai, Y., Huang, C. C., Van der Hulst, R., Meijer-Dekens, F., Bonnema, G., and Lindhout, P. 2003. QTLs for tomato powdery mildew resistance (Oidium lycopersici) in Lycopersicon parviflorum G1.1601 co-localize with two qualitative powdery mildew resistance genes. Mol. PlantMicrobe Interact. 16:169-176.

4. Bai, Y., Van der Hulst, R., Bonnema, G., Marcel, T. C., Meijer-Dekens, F., Niks, R. E., and Lindhout, P. 2005. Tomato defense to Oidium neolycopersici: Dominant $O l$ genes confer isolate-dependent resistance via a different mechanism than recessive ol-2. Mol. Plant-Microbe Interact. 18:354-362.

5. Bai, Y., Van der Hulst, R., Huang, C. C., Wei, L., Stam, P., and Lindhout, P. 2004. Mapping Ol-4, a gene conferring resistance to Oidium neolycopersici and originating from Lycopersicon peruvianum LA2172, requires multi-allelic, single-locus markers. Theor. Appl. Genet. 109:1215-1223.

6. Bardin, M., Suliman, M. E., Sage-Palloix, A. M., Mohamed, Y. F., and Nicot, P. C. 2007. Inoculum production and long-term conservation methods for cucurbits and tomato powdery mildews. Mycol. Res. 111:740-747.

7. Bock, C. H., Thrall, P. H., Brubaker, C. L., and Burdon, J. J. 2002. Detection of genetic variation in Alternaria brassicicola using AFLP fingerprinting. Mycol. Res. 106:428-434.

8. Braun, U. 1987. A Monograph of the Erysiphales (Powdery Mildews). Beih. Nova Hedwigia 89:1-700.

9. Braun, U., Cook, R. T. A., Inman, A. J., and Shin, H. D. 2002. The taxonomy of the powdery mildew fungi. Pages 13-55 in: The Powdery Mildews: A Comprehensive Treatise. R. R. Bélanger, W. R. Bushnell, A. J. Dik, and T. L. W. Carver, eds. American Phytopathological Society, St. Paul, MN. 
10. Braun, U., Takamatsu, S., Heluta, V., Limkaisang, S., Divarangkoon, R., Cook, R., and Boyle, H. 2006. Phylogeny and taxonomy of powdery mildew fungi of Erysiphe sect. Uncinula on Carpinus species. Mycol. Prog. 5:139-153.

11. Bridge, P. D., Roberts, P. J., Spooner, B. M., and Panchal, G. 2003. On the unreliability of published DNA sequences. New Phytol. 160:43-48.

12. Bulit, J., and Lafon, R. 1978. Powdery mildew of the vine. Pages 525548 in: The Powdery Mildews, D. M. Spencer, ed. Academic Press, New York

13. Cook, R. T. A., Henricot, B., Henrici, A., and Beales, P. 2006. Morphological and phylogenetic comparisons amongst powdery mildews on Catalpa in the UK. Mycol. Res. 110:672-685.

14. Cook, R. T. A., Inman, A. J., and Billings, C. 1997. Identification and classification of powdery mildew anamorphs using light and scanning electron microscopy and host range data. Mycol. Res. 101:975-1002.

15. Corpet, F. 1988. Multiple sequence alignment with hierarchical clustering. Nucleic Acids Res. 16:10881-10890.

16. Felsenstein, J. 1985. Confidence limits on phylogenies: An approach using the bootstrap. Evolution 39:783-791

17. Filatov, D. A. 2002. ProSeq: A software for preparation and evolutionary analysis of DNA sequence data sets. Mol. Ecol. Notes 2:621-624.

18. Fletcher, J. T., Smewin, B. J., and Cook, R. T. A. 1988. Tomato powdery mildew. Plant Pathol. 37:594-598.

19. Giraud, T., Villaréal, L. M. M. A., Austerlitz, F., Le Gac, M., and Lavigne, C. 2006. Importance of the life cycle in sympatric host race formation and speciation of pathogens. Phytopathology 96:280-287.

20. Groenewald, S., Van den Berg, N., Marasas, W. F. O., and Viljoen, A. 2006. The application of high-throughput AFLPs in assessing genetic diversity in Fusarium oxysporum f. sp. cubense. Mycol. Res. 110:297305.

21. Hirata, T., Cunnington, J. H., Paksiri, U., Limkaisang, S., Shishkoff, N., Grigaliunaite, B., Sato, Y., and Takamatsu, S. 2000. Evolutionary analysis of subsection Magnicellulatae of Podosphaera section Sphaerotheca (Erysiphales) based on the rDNA internal transcribed spacer sequences with special reference to host plants. Can. J. Bot. 78:1521-1530.

22. Hirata, T., and Takamatsu, S. 2001. Phylogeny and cross-infectivity of powdery mildew isolates (Podosphaera fuliginea s. lat.) on cosmos and cucumber. J. Gen. Plant Pathol. 67:1-6.

23. Hirose, S., Tanda, S., Kiss, L., Grigaliunaite, B., Havrylenko, M., and Takamatsu, S. 2005. Molecular phylogeny and evolution of the maple powdery mildew (Sawadaea, Erysiphaceae) inferred from nuclear rDNA sequences. Mycol. Res. 109:912-922.

24. Huang, C. C., Biesheuvel, J., Lindhout, P., and Niks, R. E. 2000. Host range of Oidium lycopersici occurring in the Netherlands. Eur. J. Plant Pathol. 106:465-473.

25. Inuma, T., Khodaparast, S. A., and Takamatsu, S. 2007. Multilocus phylogenetic analyses within Blumeria graminis, a powdery mildew fungus of cereals. Mol. Phylogenet. Evol. 44:741-751.

26. Jankovics, T. 2007. First report of powdery mildew (Oidium sp.) on greater celandine (Chelidonium majus). Plant Pathol. 56:353.

27. Jankovics, T., and Szentiványi, O. 2006. First report of powdery mildew on Sedum alboroseum in Europe. Plant Pathol. 55:297.

28. Jones, H., Whipps, J. M., and Gurr, S. J. 2001. The tomato powdery mildew fungus Oidium neolycopersici. Mol. Plant Pathol. 2:303-309.

29. Kashimoto, K., Matsuda, Y., Matsutani, K., Sameshima, T., Kakutani, K., Nonomura, T., Okada, K., Kusakari, S., Nakata, K., Takamatsu, S., and Toyoda, H. 2003. Morphological and molecular characterization for a Japanese isolate of tomato powdery mildew Oidium neolycopersici and its host range. J. Gen. Plant Pathol. 69:176-185.

30. Kashimoto, K., Sameshima, T., Matsuda, Y., Nonomura, T., Oichi, W., Kakutani, K., Nakata, K., Kusakari, S., and Toyoda, H. 2003. Infectivity of a Japanese isolate of Oidium neolycopersici KTP-01 to a European tomato cultivar resistant to O. lycopersici. J. Gen. Plant Pathol. 69:406408.

31. Khodaparast, S. A., Takamatsu, S., and Hedjaroude, G. A. 2001. Phylogenetic structure of the genus Leveillula (Erysiphales: Erysiphaceae) inferred from the nucleotide sequences of the rDNA ITS region with special reference to the L. taurica species complex. Mycol. Res. 105:909918.

32. Kiss, L. 2005. Powdery mildews as invasive plant pathogens: New epidemics caused by two North American species in Europe. Mycol. Res. 109:259-260

33. Kiss, L., Bolay, A., Takamatsu, S., Cook, R. T. A., Limkaisang, S., AleAgha, N., Szentiványi, O., Boal, R. J., and Jeffries, P. 2002. Spread of the North American snowberry powdery mildew fungus, Erysiphe symphoricarpi (syn. Microsphaera symphoricarpi), to Europe. Mycol. Res. 106:1086-1092.

34. Kiss, L., Cook, R. T. A., Saenz, G. S., Cunnington, J. H., Takamatsu, S., Pascoe, I., Bardin, M., Nicot, P. C., Sato, Y., and Rossman, A. Y. 2001. Identification of two powdery mildew fungi, Oidium neolycopersici sp. nov. and $O$. lycopersici, infecting tomato in different parts of the world. Mycol. Res. 105:684-697.

35. Kiss, L., Khosla, K., Jankovics, T., Niinomi, S., Braun, U., and Takamatsu, S. 2006. A morphologically ill-founded powdery mildew species, Pleochaeta indica, is recognized as a phylogenetic species based on the analysis of the nuclear ribosomal DNA sequences. Mycol. Res. 110:1301-1308.

36. Kiss, L., Takamatsu, S., and Cunnington, J. H. 2005. Molecular identification of Oidium neolycopersici as the casual agent of the recent tomato powdery mildew epidemics in North America. Plant Dis. 89:491496.

37. Kumar, S., Tamura, K., Jakobsen, I. B., and Nei, M. 2001. MEGA2: Molecular evolutionary genetics analysis software. Bioinformatics 17:12441245.

38. LaMondia, J. A., Smith, V. L., and Douglas, S. M. 1999. Host range of Oidium lycopersicum on selected solanaceous species in Connecticut. Plant Dis. 83:341-344.

39. Lebeda, A., and Mieslerová, B. 1999. Identification, occurrence and host range of tomato powdery mildew (Oidium lycopersici) in the Czech Republic. Acta Phytopathol. Hun. 34:13-25.

40. Lebeda, A., and Mieslerová, B. 2002. Variability in pathogenicity of Oidium neolycopersici on Lycopersicon species. Z. Pflanzenkr. Pflanzenschutz 109:129-141.

41. Lindhout, P., Pet, G., and Van der Beek, H. 1994. Screening wild Lycopersicon species for resistance to powdery mildew (Oidium lycopersicum). Euphytica 72:43-49.

42. Lushai, G., and Loxdale, H. D. 2002. The biological improbability of a clone. Genet. Res. 79:1-9.

43. Matsuda, Y., Kashimoto, K., Takikawa, Y., Aikami, R., Nonomura, T., and Toyoda, H. 2001. Occurrence of new powdery mildew on greenhouse tomato cultivars. J. Gen. Plant Pathol. 67:294-298.

44. Matsuda, Y., Mori, Y., Sakano, Y., Nishida, M., Tarumoto, K., Nonomura, T., Nishimura, H., Kusakari, S., and Toyoda, H. 2005. Screening of wild Lycopersicon species for resistance to Japanese isolate of tomato powdery mildew Oidium neolycopersici. Breed. Sci. 55:355-360.

45. Matsuda, Y., Sameshima, T., Moriura, N., Inoue, K., Nonomura, T., Kakutani, K., Nishimura, H., Kusakari, S., Takamatsu, S., and Toyoda, H. 2005. Identification of individual powdery mildew fungi infecting leaves and direct detection of gene expression by single conidium polymerase chain reaction. Phytopathology 95:1137-1143.

46. Matsuda, S., and Takamatsu, S. 2003. Evolution of host-parasite relationship of Golovinomyces (Ascomycete: Erysiphaceae) inferred from nuclear rDNA sequences. Mol. Phylogenet. Evol. 27:314-327.

47. McDonald, B. A. 1997. The population genetics of fungi: Tools and techniques. Phytopathology 87:448-453.

48. Mieslerová, B., and Lebeda, A. 1999. Taxonomy, distribution and biology of the tomato powdery mildew (Oidium lycopersici). Z. Pflanzenkr. Pflanzenschutz 106:140-157.

49. Mori, Y., Sato, Y., and Takamatsu, S. 2000. Evolutionary analysis of the powdery mildew fungi using nucleotide sequences of the nuclear ribosomal DNA. Mycologia 92:74-93.

50. Nei, M., and Li, W. H. 1979. Mathematical model for studying genetic variation in terms of restriction endonucleases. Proc. Natl. Acad. Sci. USA 76:5269-5273.

51. Niks, R. E. 1987. Nonhost plant species as donors for resistance to pathogens with narrow host range. I. Determination of nonhost status. Euphytica 36:841-852.

52. Núñez, Y., Gallego, J., Ponz, F., and Raposo, R. 2006. Analysis of population structure of Erysiphe necator using AFLP markers. Plant Pathol. 55:650-656.

53. Oichi, W., Matsuda, Y., Nonomura, T., Toyoda, H., Xu, L., and Kusakari, S. 2006. Formation of conidial pseudochains by tomato powdery mildew Oidium neolycopersici. Plant Dis. 90:915-919.

54. Page, R. D. M. 1996. TreeView: An application to display phylogenetic trees on personal computers. Comput. Appl. Biosci. 12:357-358.

55. Posada, D., and Crandall, K. A. 1998. MODELTEST: Testing the model of DNA substitution. Bioinformatics 14:817-818.

56. Radišek, S., Jakše, J., Simoncic, A., and Javornik, B. 2003. Characterization of Verticillium albo-atrum field isolates using pathogenicity data and AFLP analysis. Plant Dis. 87:633-638.

57. Saenz, G. S., and Taylor, J. W. 1999. Phylogeny of the Erysiphales (powdery mildews) inferred from internal transcribed spacer ribosomal DNA sequences. Can. J. Bot. 77:150-168.

58. Staden, R., Beal, K. F., and Bonfield, J. K. 2000. The Staden package, 1998. Method Mol. Biol. 132:115-130.

59. Swofford, D. L. 2003. PAUP*. Phylogenetic analysis using parsimony (*and other methods). Version 4. Sinauer Associates, Sunderland, MA.

60. Szentiványi, O., Kiss, L., Russell, J. C., Kovács, G. M., Varga, K., Jankovics, T., Lesemann, S., Xu, X., and Jeffries, P. 2005. Ampelomyces mycoparasites from apple powdery mildew identified as a distinct group 
based on single-stranded conformation polymorphism analysis of the rDNA ITS region. Mycol. Res. 109:429-438.

61. Taylor, J. W., Jacobson, D. J., Kroken, S., Kasuga, T., Geiser, D. M., Hibbett, D. S., and Fisher, M. C. 2000. Phylogenetic species recognition and species concepts in fungi. Fungal Genet. Biol. 31:21-32.

62. Takamatsu, S. 2004. Phylogeny and evolution of the powdery mildew fungi (Erysiphales, Ascomycota) inferred from nuclear ribosomal DNA sequences. Mycoscience 45:147-157.

63. Trottin-Caudal, Y., Fournier, C., Leyre, J. M., Decognet, V., Romiti, C., Nicot, P., and Bardin, M. 2003. Efficiency of a plant extract from Reynoutria sachalinensis (Milsana) to control powdery mildew on tomato (Oidium neolycopersici). Pages 11-15 in: Greenhouse Tomato Integrated Crop Protection, Organic Production. Proceedings of an International Symposium on Greenhouse Tomato. Editions CTIFL, Paris, France.

64. Urbanietz, A., and Dunemann, F. 2005. Isolation, identification and molecular characterization of physiological races of apple powdery mildew (Podosphaera leucotricha). Plant Pathol. 54:125-133.

65. Vági, P., Kovács, G. M., and Kiss, L. 2007. Host range expansion in a powdery mildew fungus (Golovinomyces sp.) infecting Arabidopsis thaliana: Torenia fournieri as a new host. Eur. J. Plant Pathol. 117:89-93.
66. Van de Peer, Y., and De Wachter, R. 1994. TREECON for Windows: A software package for the construction and drawing of evolutionary trees for the Microsoft Windows environment. Comput. Appl. Biosci. 10:569570.

67. Vos, P., Hogers, R., Bleeker, M., Reijans, M., Van de Lee, T., Hornes, M., Frijters, A., Pot, J., Peleman, J., Kuiper, M., and Zabeau, M. 1995. AFLP: A new technique for DNA fingerprinting. Nucleic Acids Res. 23:44074414.

68. Whipps, J. M., Budge, S. P., and Fenlon, J. S. 1998. Characteristics and host range of tomato powdery mildew. Plant Pathol. 47:36-48.

69. Wyand, R. A., and Brown, J. K. M. 2003. Genetic and forma specialis diversity in Blumeria graminis of cereals and its implications for host pathogen co-evolution. Mol. Plant Pathol. 4:187-198.

70. Xiao, S., Charoenwattana, P., Holcombe, L., and Turner, J. G. 2003. The Arabidopsis genes $R P W 8.1$ and $R P W 8.2$ confer induced resistance to powdery mildew diseases in tobacco. Mol. Plant-Microbe Interact. 16:289-294.

71. Zhang, J. X., Fernando, W. G. D., and Xue, A. G. 2003. Virulence and genetic variability among isolates of Mycosphaerella pinodes. Plant Dis. 87:1376-1383 